\title{
Professional Reflection a Cradle of Student Teacher's Professional Development
}

\author{
Muhammad Zafar Iqbal \\ Teaching Research Associate, Department of Education, International Islamic University Islamabad, Pakistan \\ Email zafar.phdedu57@iiu.edu.pk \\ Porf. Dr. N. B. Jumani \\ Professor, Department of Education, International Islamic University Islamabad, Pakistan \\ nb.jumani@iiu.edu.pk

\section{Dr. Saeed-ul-Hassan Chishti} \\ Assistant Professor/Project Director, Institute of Professional Development, \\ International Islamic University Islamabad, Pakistan
}

\section{Doi:10.5901/mjss.2015.v6n3s1p376}

\begin{abstract}
The emergence of connotation of reflective practices within the field of teacher education has resulted in a greater need for student teachers to consider the effectiveness of their teaching practices to meet the increased levels of accountability that is associated with their professional development. This paper provided an examination of the potential contribution of reflection for the development of effective teaching skills among student teachers during practicum course by utilizing both quantitative and qualitative research methods. This paper aimed to study the potential links between reflective practices and professional development of student teachers. Paper also examines the reflective practices of student teachers. The results revealed that reflections on professional practices supported student teachers to improve their relations with students and colleagues. Student teachers reported that they got self-awareness, they were able to understand the knowledge-in-action which enhanced student teachers skills for delivery of lesson during practicum.
\end{abstract}

Keywords: Reflections, Reflective Practices, Professional Development, Student Teachers, Teaching Practicum

\section{Introduction}

Reflections lead teachers towards effective professional actions. Relevantly the emerging prophesies of reflective practice and mentoring literature within the field of teacher education is intrinsically linked with the personal and professional development of teachers (Martindale \& Collins, 2007; Woodcock et al., 2008). Expansion of understanding of the links existing between reflective practice and a more holistic conceptualization of effective teaching practices, as well as the way in which reflection can be integrated more systematically into teachers professional development would have weighty implications for professionals and governing bodies (Corpley, 2009). Human beings learn wisdom by three methods: first by reflection, which is noblest; second, by imitation which is easiest; and third by experience, which is the bitterest (Confucius). Although experiential learning is helpful for teachers in providing professional knowledge and ideas about how to monitor learners, yet the sequencing of the stages of experiential learning may be problematic (Corpley, 2009). Dewey has defined reflective practice is an active, persistent, and careful consideration of an action in the light of reasons and possible consequences already faced. Dewey has argued that when professionals failed to find out readymade solutions to solve out a professional puzzle, they involved in critical thinking which leads toward reflective practice, which begins when professional encounter a puzzle of practice (Zeichner \& Liston, 2013). John Dewey has made a distinction between impulsive actions, routine actions and reflective actions while introducing the concept of reflective learning. Impulsive actions based on trial and error learning, routine actions based on traditional ways of learning approved by the authorities and reflective actions based on self-reflections (Ferguson 2011). Dewey has provided ambiguous explanation of the connotation of reflective practice (Mayer, 2009). Donald Schon described that teachers often face undefined multiple facets problems (swampy lowlands) not having perfect solutions during teaching process. Application of traditional professional knowledge to solve out a problem bears no fruit then they attempt to find 
out solutions through reflective practices. Schon has used various terms to clarify the concept of reflective practice e.g reflection in action and reflection on action. Reflective practice refers active evaluation of one's own thoughts and actions. The connotation of reflection also refers to critical thinking, thinking on feet, exploration of experiences to become aware of; who we are? what we do? what are our beliefs? how we think and how we act as a professional? (Schon, 1987). Briefly, what is and what might be? Schon has emphasized that as professionals teachers ought to question their beliefs, attitudes, values, professional knowledge, subject knowledge, and theories working behind their practices to grow as professional.

Many studies have been conducted around the globe to study the notion of reflective practices, but there is dearth of research on this connotation in Pakistan. Results of many studies conducted revealed that involvement of teachers in reflective practices affected their professional teaching practices and helped them out to construct professional knowledge (Greenwood, 1998: Bulman \& Schutz 2004; Pedro, 2005). Habit of reflective practices empowered teachers to become successful decision makers (Anita, 2011; Zeichner \& Liston, 2013; Ghye, 2002 \& Roadman, 2010). Involvement of teachers in reflective practices facilitated teachers to always take the responsibility of their professional actions taken during teaching learning process (McGregor \& Cartwright, 2011 \& Osterman \& Kottkamp, 2004). Reflective teachers grow and develop throughout their career and meet the learning needs of their students in a better way as compared to nonreflective teachers (Larrivee \& Cooper, 2006; Rodgers, 2002; Zengaro \& Nejad 2007). Present study was undertaken to study the reflective practices of student teachers during practicum.

\section{Literature Review}

Vitality of professional development of student teachers has been acknowledged throughout the world. In Pakistani context many efforts have been make for the professional development of teachers. Recently, Higher Education Commission has included four units on reflective practices and critical thinking to empower the student teachers to involve in reflections and critical thinking and take the responsibility of their own professional development (HEC, 2006). UNESCO, (2006) report exposed that Government of Pakistan has undertaken many initiatives to start various professional development programmes for, but main focus of many educational policies remained to enhance the access to education in Pakistan (Unesco, 2006). Reflection and mentoring are interlinked terms, but a deliberate difference exists between two terms. The connotations of reflective practices expect teachers to take the responsibility of their own professional development. While in mentoring mentor is expected to take the responsibility of professional development of mentees. Mentoring is also a type of reflective practices. Punjab Education Department has formally started mentoring programmes since 2007 under the umbrella of Directorate of Staff Development (DSD) for the professional development of elementary teachers. Mentoring refers an interaction between a more experienced teacher and a less experienced teacher. Experienced teacher provides professional guidance and counseling to the mentee to take meticulous licensed actions. Mentor attempts to nurture the growth of less experienced teachers in making significant transitions in knowledge at work (Johnson, 2003). Mentoring is considered a cost-effective way to upgrade the teaching skills of teachers to enhance retention and to increase the level of job satisfaction. It helps the newly recruited teachers to learn about school culture and to function effectively within the context of the school system.

Reflection and mentoring expand more the opportunities for professional development of teachers as compared to traditional ways of professional growth (Huwe, 2003). Mentoring is a well-built long-term relationship between a senior and junior teacher to develop the listening, trust building, determining learning goals and encourage teachers to manage their relationships in professional context (Eby \& Allen, 2002). Different kinds of mentoring emerged through previous research literature. Darwin, (2000) has mentioned following types (1) Task-Based Mentoring; focused to acquire new knowledge or skills to perform a new role, (2) Experience-based mentoring; focused to pair expert teacher with newly inducted teacher to teach him/her about professional roles (3) Just-in-time mentoring; where expert teacher (mentor) anticipate the professional learning needs of the mentee (4) One-to-one mentoring; emphasized on working of one senior teacher with one junior teacher to assist him/her about professional teaching actions (5) Team mentoring; group of expert teacher works with groups of junior teachers/mentees to guide them about their professional roles and (5) Formal mentoring; where mentor explicit expectations of the mentee by specifying mentee characteristics such as timelines, achievements, progress reporting, benchmarks, and communications skills (Darwin, 2000).

Reflective practice refers self-evaluation of professional practices for sake of development. Bolton, (2010) has quoted an example of reflection "If $90 \%$ students of a reflective teacher failed in a test. The teacher will not blame students or circumstances. Rather teacher reflects over the nature of learning material and questions the appropriateness of teaching method (Bolton, 2010). Reflective practices also refers personal and professional reflections, sharing of expertise with others professionals having common interests, taking feedback from students, planning teaching activities 
in the light of students feedback, preparation of professional portfolios, reflection over portfolios to identify the gaps of professional practice, working with learning communities, professional collaborations and co-teaching are key elements of reflective practices (Taylor, 1997). Reflective practices increase the transfer of learning and provide a range of activities that accommodates different learning styles of students. It also provides opportunities to the teachers to take and follow up individual feedback of students (Taylor, 1997; Goe et al. (2008) and Ferguson, (2010) described that student's ability to furnish feedback vary from class to class, even students from same class may rate a teacher as average, good or excellent teacher. Usually students do not have knowledge about teaching learning strategies, professional standards for teachers, classroom management techniques and curriculum. Student rarely understand teacher's responsibilities. Junior level students cannot discriminate between effective and ineffective teaching methods (Ferguson, 2010; Goe et al., 2008). Students of a class may grade one teacher as average, while students of another class may grade the same teacher as an ideal teacher.

Habit of reflection enables student teachers to investigate the effectiveness of their own teaching practices (Myers, 2009). National Council for Accreditation of Teacher Education (NCATE) has avowed that teacher's involvement in reflective practices should be mandatory so that they may reflect on the gaps of their teaching practices (NACTE, 2008). The notion of reflective practices has gained momentum attention over the last twenty years, despite that collective dimension or interactional aspects of reflective practices have been largely ignored (Farrell, 2004; Marshall, 2008; Fathi \& Behzadpour, 2011). Theoretically, the concept of reflective practices is very rich but has not been translated into to practice yet. There is no evidence that involvement of teachers in reflective practices ended in better professional learning of novice teachers and necessarily leads students towards higher academic achievement (Akbari, 2007; Fathi \& Behzadpour, 2011). Reflective practice is the means by which learning, renewal, and growth continue throughout the career of teachers.

Reflective teachers have greater self-awareness about their teaching methods and always put serious efforts to bring improvement in their teaching practices. Student teachers can use reflective practices as a tool to evaluate their professional practices by raising critical questions e.g did the lesson really go well? which parts of the lesson were more effective for students? why some parts of the lesson were not effective? How I can teach differently tomorrow? Professional reflections enable teachers to identify their shortcomings of their practices instead of blaming others (Brockbank \& McGill, 2007).

\section{Objectives of the Study}

Study was conducted to achieve the following objectives:

1. To study the reflective practices of student teachers during teaching practicum in Islamabad and Rawalpindi.

2. To study the effects of reflective practices on the professional development of student teachers in Islamabad and Rawalpindi.

\section{Research Questions}

The study was guided by following research questions:

1. What are the opportunities offered to student teachers by teacher cooperating schools to ensure their involvement in reflective practices?

2. What kind of collaboration exists among student teachers and practicum school teachers to initiate reflective practices in Islamabad and Rawalpindi?

3. To what extend reflective practices of student teachers affect their professional development during practicum?

4. How do student teachers initiate reflective practices during teaching practice?

\section{Importance of the Study}

Higher Education Commission has included four units on reflective practices and critical thinking in Bachelor of Education Programme curriculum during 2006 (HEC, 2006), but merely addition of units on reflective practices into the curriculum is not enough. Student teachers also need to show commitment to practice what teacher training institutions preached them about reflective practices during course work. Therefore, there is a need to study that how student's teachers involve in reflective practices and how teacher training institutions and cooperating school teachers assist student teachers to accelerate their teaching tactics to promote and sustain their student's teachers professional development through 
reflective practices? Otherwise, the dream to accelerate student teachers professional development will not change into reality. This study is multifaceted attempt to understand the reflective practices of student teachers and designates the views of student teachers about reflective practices. How student teachers think over their professional practices, values and attitudes as a result of reflective practices? How student teachers reflect over their own professional mistakes and how they put self-efforts to understand and improve their pedagogical skills in the light of reflective practices. Therefore, findings of the study may be imperative for student teachers, cooperating school teachers and teacher training institutions in Pakistani context.

\section{Methodology}

Study based on mixed method descriptive survey approach. Population of the study comprised of male and female student teachers enrolled in B.Ed programme during 2012 and 2013 at teacher training colleges and universities department of education in Islamabad and Rawalpindi, Pakistan. All the population was selected to collect quantitative data. Questionnaire was personally distributed to 910 (female $=650$ male=150) student teachers. But 800 respondents returned the questionnaire. Qualitative data was collected through interview $10 \%$ of the total sample i.e 80 student teachers were interviewed. Percentage wise distribution of sample was male was $18.8 \%$ and female $81.2 \%$. It can be argued that majority of the respondents were female by size of enrollment due to existing enrollment trends in B.Ed programme. Overall response rate was $87.91 \%$. Convergent Parallel Design was adopted to collect quantitative and qualitative data. This design permits researchers to collect quantitative and qualitative data respectively and make separate analysis of both types of the data. According to Creswell (2011) Convergent Parallel Design allows researcher to combine both type of data in a single study and it is major strength of this design. Quantitative data provides evidences for generalizability of the findings, whereas, qualitative data bids information about the context or settings of the study (Cresswell, 2011). Questionnaire comprising of 12 items was developed on the basis of indicators of reflective practices appeared in previous research literature. The questionnaire was pilot tested before long scale study. Reliability coefficient of the questionnaire was measured .93 through SPSS version 16 by applying Cronbach Alpha. Similarly validity of the questionnaire was checked in consultation with experts. Questionnaire was personally administrated to the sample as well dispatched to the respondents through mail. Researcher got informed consent of the respondents before administration of the questionnaire. Similarly researcher has taken informed consent of the respondents in advance for interview. Researcher ensured the respondents that all the information will be kept confidential. Therefore, names and personal information is not mentioned anywhere through-out the report. Details about population and sample were as under:

\section{Population \& Sample}

Age group wise distribution of respondents was as under:

Table 1: Age Groups of the Respondents

\begin{tabular}{cccccc}
\hline \multicolumn{7}{c}{ Student Teachers } \\
\hline Age group & Frequency & Percentage & Age group & Frequency & Percentage \\
\hline Below 20 years & 89 & $11.1 \%$ & $31-35$ years & 13 & $1.6 \%$ \\
\hline 20-25 years & 536 & $67.0 \%$ & Above 35 years & 01 & $1 \%$ \\
\hline 26-30 years & 120 & $15.0 \%$ & No Answer about age & 41 & $5.1 \%$ \\
\hline \multicolumn{7}{c}{$\mathrm{N}=800$} \\
\hline
\end{tabular}

Table 1 shows that majority (67\%) of student teachers were 20 to 25 years old and majority of respondents formed a young group., $11.1 \%$ were less than 20 years old, $15 \%$ were belonging to middle age group i.e $26-30$ years, 1.6\% were 31 to 45 years old. While only $1 \%$ respondents were belonging to above 35 years age group. Whereas, (5.1\%) student teachers provided no answer about their age group. Majority (76.6\%) student teachers were having no professional qualification when they joined B.Ed programme. $5.2 \%$ were having Primary Teaching Certificate, $7 \%$ were having Certificate in Teaching, 2\% completed Arabic Teaching Training Certificate prior to their enrollment in B.Ed programme. 9.1\% completed Diploma in Education before their enrollment in B.Ed programme. It can be argued that most of student teachers were simply graduate and not having no professional qualification when they got admission in Bachelor of Education programme. 


\section{Results}

Table 2: Student Teachers Involvement in Reflective practices

\begin{tabular}{|c|c|c|c|c|c|}
\hline Statement & Responses & Freq. & $\%$ & Mean & S.D \\
\hline \multirow[t]{6}{*}{$\begin{array}{l}\text { I reflect over students discourteous attitude during teaching } \\
\text { process }\end{array}$} & $\begin{array}{l}\text { Strongly } \\
\text { Disagree }\end{array}$ & 54 & $6.8 \%$ & \multirow{6}{*}{3.63} & \multirow{6}{*}{1.25} \\
\hline & Disagree & 152 & $19.0 \%$ & & \\
\hline & Undecided & 43 & $5.4 \%$ & & \\
\hline & Agree & 336 & $42.0 \%$ & & \\
\hline & Strongly Agree & 215 & $26.9 \%$ & & \\
\hline & $\mathrm{N}=$ & 800 & $100 \%$ & & \\
\hline \multirow[t]{6}{*}{$\begin{array}{l}\text { I plan strategies to overcome students discourteous attitude } \\
\text { during my lesson }\end{array}$} & $\begin{array}{l}\text { Strongly } \\
\text { Disagree }\end{array}$ & 45 & $5.6 \%$ & \multirow{6}{*}{3.58} & \multirow{6}{*}{1.27} \\
\hline & Disagree & 185 & $23.1 \%$ & & \\
\hline & Undecided & 58 & $7.2 \%$ & & \\
\hline & Agree & 285 & $35.6 \%$ & & \\
\hline & Strongly Agree & 227 & $28.4 \%$ & & \\
\hline & $\mathrm{N}=$ & 800 & $100 \%$ & & \\
\hline \multirow{6}{*}{$\begin{array}{l}\text { I attempt to overcome my unwanted practices (shyness, } \\
\text { shivering, repetition of word \& under-confidence) during } \\
\text { teaching process }\end{array}$} & $\begin{array}{l}\text { Strongly } \\
\text { Disagree }\end{array}$ & 43 & 5.4 & \multirow{6}{*}{3.73} & \multirow{6}{*}{1.21} \\
\hline & Disagree & 134 & 16.8 & & \\
\hline & Undecided & 58 & 7.2 & & \\
\hline & Agree & 325 & 40.6 & & \\
\hline & Strongly Agree & 240 & 30.0 & & \\
\hline & $\mathrm{N}=$ & 800 & $100 \%$ & & \\
\hline \multirow[t]{6}{*}{$\begin{array}{l}\text { When I teach to the students, I reflect over class room discipline } \\
\text { to maintain class-room momentum }\end{array}$} & $\begin{array}{l}\text { Strongly } \\
\text { Disagree }\end{array}$ & 49 & 6.1 & \multirow{6}{*}{3.67} & \multirow{6}{*}{1.20} \\
\hline & Disagree & 130 & 16.2 & & \\
\hline & Undecided & 70 & 8.8 & & \\
\hline & Agree & 339 & 42.4 & & \\
\hline & Strongly Agree & 212 & 26.5 & & \\
\hline & $\mathrm{N}=$ & 800 & $100 \%$ & & \\
\hline \multirow[t]{6}{*}{ I think about smooth rolling of lesson plan during lesson } & $\begin{array}{l}\text { Strongly } \\
\text { Disagree }\end{array}$ & 39 & 4.9 & \multirow{6}{*}{3.62} & \multirow{6}{*}{1.28} \\
\hline & Disagree & 190 & 23.8 & & \\
\hline & Undecided & 56 & 7.0 & & \\
\hline & Agree & 263 & 32.9 & & \\
\hline & Strongly Agree & 252 & 31.5 & & \\
\hline & $\mathrm{N}=$ & 800 & $100 \%$ & & \\
\hline \multirow[t]{6}{*}{$\begin{array}{l}\text { Whenever, I teach controversial contents in class I reflect over } \\
\text { the contents before teaching }\end{array}$} & $\begin{array}{l}\text { Strongly } \\
\text { Disagree }\end{array}$ & 74 & 9.2 & \multirow{6}{*}{3.40} & \multirow{6}{*}{1.28} \\
\hline & Disagree & 164 & 20.5 & & \\
\hline & Undecided & 89 & 11.1 & & \\
\hline & Agree & 313 & 39.1 & & \\
\hline & Strongly Agree & 160 & 20.0 & & \\
\hline & $\mathrm{N}=$ & 800 & $100 \%$ & & \\
\hline \multirow[t]{6}{*}{$\begin{array}{l}\text { During teaching process I plan strategies to maintain classroom } \\
\text { discipline }\end{array}$} & $\begin{array}{l}\text { Strongly } \\
\text { Disagree }\end{array}$ & 62 & 7.8 & \multirow{6}{*}{3.67} & \multirow{6}{*}{1.28} \\
\hline & Disagree & 136 & 17.0 & & \\
\hline & Undecided & 50 & 6.2 & & \\
\hline & Agree & 309 & 38.6 & & \\
\hline & Strongly Agree & 243 & 30.4 & & \\
\hline & $\mathrm{N}=$ & 800 & $100 \%$ & & \\
\hline \multirow[t]{2}{*}{$\begin{array}{l}\text { When I ask questions from my students I reflect over my } \\
\text { hesitation to overcome }\end{array}$} & $\begin{array}{l}\text { Strongly } \\
\text { Disagree }\end{array}$ & 80 & 10.0 & \multirow[t]{2}{*}{3.41} & \multirow[t]{2}{*}{1.33} \\
\hline & Disagree & 185 & 23.1 & & \\
\hline
\end{tabular}




\begin{tabular}{|c|c|c|c|c|c|}
\hline Statement & Responses & Freq. & $\%$ & Mean & S.D \\
\hline & Undecided & 49 & 6.1 & & \\
\hline & Agree & 299 & 37.4 & & \\
\hline & Strongly Agree & 187 & 23.4 & & \\
\hline & $\mathrm{N}=$ & 800 & $100 \%$ & & \\
\hline \multirow[t]{6}{*}{ I reflect over my practices to improve my pedagogical skills } & $\begin{array}{l}\text { Strongly } \\
\text { Disagree }\end{array}$ & 191 & 23.9 & \multirow{6}{*}{2.61} & \multirow{6}{*}{1.46} \\
\hline & Disagree & 102 & 12.8 & & \\
\hline & Undecided & 58 & 7.2 & & \\
\hline & Agree & 260 & 32.5 & & \\
\hline & Strongly Agree & 189 & 23.6 & & \\
\hline & $\mathrm{N}=$ & 800 & $100 \%$ & & \\
\hline \multirow[t]{6}{*}{$\begin{array}{l}\text { I reflect on my professional mistakes and I attempt to rectify my } \\
\text { mistakes on the spot }\end{array}$} & $\begin{array}{l}\text { Strongly } \\
\text { Disagree }\end{array}$ & 61 & $7.6 \%$ & \multirow{6}{*}{3.55} & \multirow{6}{*}{1.28} \\
\hline & Disagree & 165 & $20.6 \%$ & & \\
\hline & Undecided & 52 & $6.5 \%$ & & \\
\hline & Agree & 314 & $39.2 \%$ & & \\
\hline & Strongly Agree & 208 & $26.0 \%$ & & \\
\hline & $\mathrm{N}=$ & 800 & $100 \%$ & & \\
\hline \multirow[t]{6}{*}{$\begin{array}{l}\text { I attempt to identify slow learners and assign them easy } \\
\text { assignments }\end{array}$} & $\begin{array}{l}\text { Strongly } \\
\text { Disagree }\end{array}$ & 51 & $6.4 \%$ & \multirow{6}{*}{3.64} & \multirow{6}{*}{1.24} \\
\hline & Disagree & 152 & $19.0 \%$ & & \\
\hline & Undecided & 50 & $6.2 \%$ & & \\
\hline & Agree & 326 & $40.8 \%$ & & \\
\hline & Strongly Agree & 221 & $27.6 \%$ & & \\
\hline & $\mathrm{N}=$ & 800 & $100 \%$ & & \\
\hline
\end{tabular}

Table 3: Views of Student Teachers about Benefits of Reflective Practices

\begin{tabular}{|c|c|c|c|c|c|c|}
\hline Sr. & Benefits of reflective practices & Responses & Freq. & $\%$ & Mean & S.D \\
\hline \multirow{2}{*}{1} & \multirow{2}{*}{$\begin{array}{l}\text { Reflective practices are helpful to develop pedagogical skills of } \\
\text { student teachers }\end{array}$} & Yes & 547 & $68 \%$ & \multirow{2}{*}{1.32} & \multirow{2}{*}{.465} \\
\hline & & No & 253 & $32 \%$ & & \\
\hline \multirow{2}{*}{2} & \multirow{2}{*}{$\begin{array}{l}\text { Reflective practices are helpful to develop good relations with } \\
\text { students }\end{array}$} & Yes & 487 & $61 \%$ & \multirow{2}{*}{1.39} & \multirow{2}{*}{.488} \\
\hline & & No & 313 & $39 \%$ & & \\
\hline \multirow{2}{*}{3} & \multirow{2}{*}{$\begin{array}{l}\text { Reflective practices are helpful to develop good relations with } \\
\text { colleagues }\end{array}$} & Yes & 526 & $66 \%$ & \multirow{2}{*}{1.34} & \multirow{2}{*}{.475} \\
\hline & & No & 274 & $34 \%$ & & \\
\hline \multirow{2}{*}{4} & \multirow{2}{*}{ Reflective practices are helpful for self-understanding } & Yes & 459 & $42 \%$ & \multirow{2}{*}{1.43} & \multirow{2}{*}{.495} \\
\hline & & No & 341 & $69 \%$ & & \\
\hline \multirow{2}{*}{5} & \multirow{2}{*}{$\begin{array}{l}\text { Involvement in reflective practices facilitate teachers to get } \\
\text { awareness about professional weakness }\end{array}$} & Yes & 578 & $73 \%$ & \multirow{2}{*}{1.28} & \multirow{2}{*}{.448} \\
\hline & & No & 222 & $27 \%$ & & \\
\hline \multirow{2}{*}{6} & \multirow{2}{*}{ Reflective practices are helpful to better understand learners } & Yes & 489 & $61 \%$ & \multirow{2}{*}{1.34} & \multirow{2}{*}{.487} \\
\hline & & No & 311 & $39 \%$ & & \\
\hline \multirow{2}{*}{7} & \multirow{2}{*}{ Reflective practices are helpful or Professional Development } & Yes & 607 & $76 \%$ & \multirow{2}{*}{1.24} & \multirow{2}{*}{.428} \\
\hline & & No & 193 & $24 \%$ & & \\
\hline \multirow{2}{*}{8} & \multirow{2}{*}{ Reflective practices have no importance } & Yes & 23 & $3 \%$ & \multirow{2}{*}{1.97} & \multirow{2}{*}{.167} \\
\hline & & No & 777 & $97 \%$ & & \\
\hline \multirow{3}{*}{9} & \multirow{3}{*}{$\begin{array}{l}\text { No Answer about benefits of reflective practices } \\
N=800\end{array}$} & Yes & 97 & $12 \%$ & \multirow{3}{*}{1.88} & \multirow{3}{*}{.327} \\
\hline & & No & 703 & $88 \%$ & & \\
\hline & & No & 92 & $68 \%$ & & \\
\hline
\end{tabular}

Table 2 shows that $68.9 \%$ student teachers student teachers were agreed that whenever their students demonstrated discourteous attitude during class they reflected over the attitude of their students. 5.4\% were uncertain in their responses, while $25.9 \%$ Student teachers replied that they do not reflect their student's disrespectful attitude. The mean score 3.63 indicated that majority of students teachers take a note of their students discourteous attitude. Similarly $71.6 \%$ student teachers agreed or strongly agreed that whenever their students demonstrated discourteous attitude during class. They reflect over such attitudes and planned strategies to overcome discourteous attitude of their students, $7.2 \%$ remained uncertain in their responses, while $28.8 \%$ respondents disagreed or strongly disagreed that they involved in 
reflection to plan strategies to overcome students' discourteous attitude during teaching process. The mean value (3.58) indicated majority of student teachers plan strategies to overcome student discourteous attitude.

Table 2 reflects that almost 70\% student teachers were strongly agreed or agreed that they reflected over their unwanted practices e.g shyness, shivering, repetition of words and under-confidence, similarly student teachers acknowledged that they also attempted to overcome their unwanted practices during teaching learning process, $7.2 \%$ were neutral in their responses, whereas, $22.1 \%$ were disagreed and strongly disagreed that they attempted to overcome unwanted practices during lesson. The mean score 3.73 shows that responses of majority of student teachers exists in the category of strongly agreed and agreed. It can be established that most of student teachers reflect over their own practices and attempted to overcome their unwanted practices.

Data reflected in Table 2 shows that $68.9 \%$ student teachers were agreed and strongly agreed that they reflect over the class room discipline to maintain class room momentum, $8.8 \%$ provided uncertain responses, whereas, $28.3 \%$ respondents strongly disagreed and disagreed that they were involved in reflection to see the deficiencies in classroom discipline and to maintain classroom discipline. The mean score 3.67 showed that majority of the respondents involve in reflection to maintain classroom discipline during class.

Table 2 reflects that $64.4 \%$ student teachers were involved in reflection in action to uphold smooth rolling of lesson plan, $7.0 \%$ opted uncertain option, while, $28.7 \%$ respondents were not agreed with the statement. The mean value 3.62 shows that majority of the student teachers involve in reflective practice to uphold smooth rolling of lesson plan. Similarly $59.1 \%$ student teachers were agreed with that they whenever they teach controversial contents to their students they reflect over the controversy of contents before teaching, $11.1 \%$ provided uncertain responses, whereas, $28.7 \%$ student teachers were strongly disagreed and disagreed. However, the mean value 3.40 shows that most of the student teachers reflect over the controversy of contents whenever, they teach controversial contents to their students. It can be established that majority of student teachers were well aware about the contents and they critically observe their own lesson.

Data given in table 2 described that $69 \%$ student teachers were strongly agree or agree that they involve in reflection to plan strategies to maintain classroom discipline during teaching process, $6.2 \%$ opted uncertain option, whereas $25 \%$ of the respondents were not agreed with the statement. Keeping in view the mean value i.e 3.67 it can be established that student teachers reflect over the practices to maintain class room discipline. This indicates student teachers involvement in reflective practices. Similarly $69 \%$ student teachers were strongly agreed and agreed that when they asked questions from their students during teaching practice they felt hesitation, but they reflect over their hesitation and attempted to overcome the hesitation. $6 \%$ provided uncertain response, while $33.2 \%$ replied that were not hesitant whenever they asked questions from their students during practices. But mean value 3.41 shows that majority of student teachers felt hesitation when they attempted to ask questions they reflected over their own hesitation to overcome.

Table 2 shows that $56.1 \%$ student teachers were strongly agreed and agreed that during lesson they reflected over their teaching practices to improve their pedagogical skills $7.2 \%$ provided uncertain response, whereas, $36.7 \%$ of the respondents disagreed that they do not reflect over their teaching practices to bring improvement. The mean value 2.61 shows that majority of student teachers attempt to improve their pedagogical skills. Similarly $65.2 \%$ Student teachers were strongly agreed or agreed that they reflect over their own teaching practices for identification and rectification of professional mistakes during teaching learning process, $6.5 \%$ provided uncertain responses, whereas, $28.2 \%$ replied that during teaching process they do not involve in reflection to identify and rectify their won professional mistakes. The mean value 3.55 indicated that majority of student teachers attempt to identify and rectify their own professional mistakes during teaching leaning process. Table 2 shows that $68.4 \%$ student teachers replied that they reflect over their learners learning abilities to identify the slow learners, $6.2 \%$ provided uncertain responses, while $25.4 \%$ respondents were disagreed that they attempt to identify slow learners. The mean value 3.64 indicates that majority of student teachers attempt to identify slow learners during teaching practicum.

Table 3 shows views of student teachers about the benefits of reflective practices for professional learning. Majority $(68 \%)$ student teachers considered that involvement in reflective practices contributed towards development of their pedagogical skills, $61 \%$ respondents replied that during practicum reflective practices contributed towards development of good relations with students, $66 \%$ student teachers thought they could develop better relations with colleagues through reflective practices, $42 \%$ responded that reflective practices helped them out to develop better selfunderstanding, $73 \%$ replied that reflective practices were helpful for them to identify their own professional weakness, $61 \%$ replied that reflective teachers facilitate them to have a better understanding of their learners, $76 \%$ responded the reflective practices contributed toward their professional development, $3 \%$ thought that reflective practices made no benefits, while $12 \%$ PTs provided no answer about the benefits of reflective practices. It can be established that majority of student teachers perceived involvement in reflective practices as a cradle for their professional development. 


\section{Discussions}

Reflective practices require open minded disposition to involve in reflective discourse to better understand and improve their own teaching practices. Results of the study of Mayers, 2009, revealed that involvement of student teachers in reflective practices in a controlled environment off and on campus improved teacher's teaching behaviours. Formal written feedback and focused discussions with students and colleagues provided an emerging evidence of student teachers professional growth and enable them to bring improvement in their teaching practice. They were able to design their teaching to promote effective learning for their students (Mayers, 2009). Similarly finings of this study showed that majority of student teachers responded that involvement in reflective practices supported them to design their lesson in the light of their students feedback. Majority of student teachers acknowledged that students feedback lead them to know the strengths and weakness of their own teaching style.

Similarly findings of the study of Egrinle (2006) revealed that student teachers regarded self-awareness as fundamental quality which was developed through the reflective practicum course. Student teachers got awareness about their own actions through videotaping of their lessons, microteaching assignments, reflective journals, student's feedback and peer's feedback (Erginel, 2006). Similarly, findings of this study revealed that majority of student teachers replied that they can identify and rectify their mistakes through student's feedback. Teachers acknowledged that they can examine their belief's structure regarding education and engagement of their students in an ongoing process of diagnosis through peer observations, reflective questions, evaluative student's feedback and critical reflections. Teacher's involvement in reflective practices is critical to cultivate self-awareness among teachers and to motive them to deal with disruptive situations without violation (Spiller, 2011). Proper usage of students' feedback may enable teacher to improve their teaching and learning environment (Burniske, \& Meibaum, 2012). Results of the study of Hajira \& Shamsa (2012) revealed that university teachers made their self-evaluation after receiving the feedback from their students and attempted to understand student's problems. Reflective university teachers were desirous to develop good relations with their students. Similarly results of this study revealed that students feedback leads student teachers to critically look into their practices for sake of improvement. Reflective teachers can find out the rationale of their teaching practices by developing a deeper understanding about their own teaching style. Ability to question and understand of own actions results in professional growth of teachers (Amoh, 2011).

\section{References}

Akbari, R. (2007). Reflections on Reflection: A critical appraisal of reflective practices in L2 Teacher education system, (35):2, 192-207.

Amoh, S.A. (2011). The Reflective and Collaborative Practices of Teachers in Ghanaian Basic

Schools: A Case Study. (Doctoral dissertation). Retrieved from http;///these.nottingham.ac.uk/2012/1/1.thesis-final.pdf.

Anita, Y. K. (2011). Reflective Practice: A Case Study of Early Childhood Teachers in Hong Kong. Hong Kong. Early Childhood Education. Vol. 10 (66-76) July 2011.

Bolton, G. (2010). Reflective practice writing and professional development (3rd Ed). California, London: SAGE publications.

Brockbank, A. \& McGill, I. (2007). Facilitating reflective learning in higher education Abingdon: Open University Press.

Bulman, C., \& Schutz, S. (2004). Reflective practices in nursing (3rd Ed). U.K: Blackwell Publishing.

Burniske, J., \& Meibaum, D. (2012). The use of student perceptual data as a measure of teaching effectiveness. SEDL, Texas Comprehensive Centre.

Corpley, B. (2009). Reflective Practice and Consultant Effectiveness: An Examination of Sport Psychology Practice (Doctoral thesis). University of Wales.

Cresswell, J. W. (2011), Educational Research: Planning, Conducting, and Evaluating Quantitative and Qualitative Research (4th Edition). New york: Pearson.

Darwin, A. (2000). Critical reflections on mentoring in work settings. Adult Education Quarterly, 50(3), 197-211.

Dewey, J. (1933). How we think. Washington: University of Wisconsin press.

Eby, L. T., \& Allen, T. D. (2002). Further investigation of protégés' negative mentoring experiences: Patterns and outcomes. Group \& Organization Management, 27(4), 456-479.

Erginel, S. S. (2006). Developing reflective teachers: A study on perception and improvement of reflection in pre-service teacher education (Doctoral dissertation), The graduate school of social sciences of Middle East Technical University).

Erginel, S. S. (2006). Developing reflective teachers: A study on perception and improvement of reflection in pre-service teacher education (Doctoral dissertation), The graduate school of social sciences of Middle East Technical University).

Farrell, T. S. (2004). Reflective practice in action: 80 reflective breaks for busy teachers. Thousand Oaks: Corwin Press.

Fathi, J. \& Behzadpour, F. (2011). Beyond Method: The Raise of Reflective Teaching. International Journal of English Linguistics Vol. 1 No. 2 (241-251) September, 2011. DOl:10.5539/ijel.v1n2p241

Ferguson, R. F. (2010). Student perceptions of teaching effectiveness. Retrieved from: http://www.gse.harvard.edu/ncte/news/ Using_Student_Perceptions_Ferguson.pdf. 
Ghaye, T., \& Lillyman, S. (2002). Reflection principles and practice for healthcare professionals. UK: Wiltshire Quay books.

Goe, L., Bell, C., \& Little, O. (2008). Approaches to evaluating teacher effectiveness. Washington DC: NSC for Teachers quality.

Greenwood, J. (1998). The role of reflection in single and double loop learning. Journal of advanced nursing practice, 27(5), 1048-1053. doi: http://www.communityhealthcarebolton.co.uk/SHA/LLL/resources/reflective/Greenwood.pdf

Hajira, B, \& Shamsa, A. (2012). Reflective practices and teacher educators: An exploratory study. International Journal of Social Science \& Education, Vol (3) (1) 2223-4934.

HEC, (2010), Curriculum of education; B. Ed (Hons.) 4 year degree program (Elementary \& Secondary, Revised 2010). Islamabad: Higher Education Commission.http://www.ncbi.nlm.nih.gov/pmc/articles/PMC1484785/

Huwe, J.M. (2002). Toward a typology of mentorship dysfunction in graduate school. Psychotherapy: Theory/Research/Practice/ Teaching, 39, 44-55.

Johnson, W. B., and Huwe, J. (2003). Getting mentored in graduate school. Washington, DC: American Psychological Association.

Larrivee, B., \& Cooper, M. J. (2006). An educator's guide to teacher reflection. USA: Cengage Learning.

Martindale, A., \& Collins, D. (2007). Enhancing the evaluation of effectiveness with professional judgment and decision making. The Sport Psychologist, 21, 458-474.

McGregor D,, Cartwright, L., (2011). Developing reflective practice: A guide for beginning teachers. England: Open University Press. Retrieved from http://books.google.com.pk/books?id=yT6nWpvPwCcC\&pg=PA180\&lpgf=true.

Myers, P. Z. (2009). An analysis of the concept reflective practice and an investigation into the development of student teachers' reflective practice within the context of action research. (Doctoral dissertation). Brunel University, UK.

Osterman, K. E, \& Kottkamp, R. B. (2004) Reflective practice for educators: Professional Development to improve student learning (2nd ed.). Newbury Park, CA: Corwin Press

Pedro, J. Y. (2005). Reflecting in teacher education: Exploring pre-service teachers' meaning of reflective practice. Reflective Practice, Vol. 6 (1), $49-66$.

Roadman, G.J. (2010). Facilitating the teaching learning process through the reflective Engagement of pre-service teachers. Australian journal of teacher education. Volume 35, (2) March 2010. Pp20-34. DOI: http://ro.ecu.edu.au/aite/vol35/iss2/2/

Rodgers, C. (2002). Defining reflection another look at John Dewey. Teachers College Record,(104). 842-866. DOl: http://www.tcrecord. org/content.asp?contentid $=10890$

Schon, D. (1987). Educating the reflective practitioner. San Francisco, CA: Jossy Bass.

Schon, D. (1988). Coaching in reflective thinking reflection in teacher education. New York: Teachers college press. Retrieved from: educ.ubc.ca/westcast/documentsCAST3.pdf.

Schon, D.A. (1983). The reflective practitioner how professionals think in action. San Francisco: Jossey-Bass, Inc.

Schon, D.A. (1983). The reflective practitioner how professionals think in action. San Francisco: Jossey-Bass, Inc.

Schon, D.A. (1996). Educating the reflective practitioner: Toward a new design for teaching and learning in the professions. San Francisco: Jossey-Bass, Inc.

Spiller, D. (2011). Peer Observation: Teaching Development. New Zealand: Private Bag.

Taylor, M. (1997). Transfer of Learning: Planning Workplace Education Programs. Ottawa, CA: National Literacy Secretariat.

UNESCO, (2006). Strategic framework for teacher education and professional development in Pakistan. Islamabad: Unesco. Retrieved from http//unesco.org.pk/education/teachereducation/files.pdf

Woodcock, C., Richards, H., \& Mugford, A. (2008). Quality counts: Critical features for neophyte professional development. The Sport Psychologist, 22, 491-506.

Zeichner, K. M. \& Liston, D.P. (2013). Reflective Teaching An Introduction. New York. Routledge.

Zeichner, K. M. \& Liston, D.P. (2013). Reflective Teaching An Introduction. New York. Routledge.

Zengzro, F., \& Nejad, I, A. (2007). Exploring reflective engagement that promotes understanding in college classrooms. International Journal for the scholarship of teaching and learning. 1(2) 1-18. DOI: http://dspacepord.georgiasouthern.edu:8080/jspui/handle /10518/4173

Zengzro, F., \& Nejad, I, A. (2007). Exploring reflective engagement that promotes understanding in college classrooms. International Journal for the scholarship of teaching and learning. 1(2) 1-18. DOl: http://dspacepord.georgiasouthern.edu:8080/jspui/handle/ $10518 / 4173$ 